\title{
Assessing the solutions to tobacco control's funding gap problem
}

\author{
Sara Rose Taylor 지 , Ryan Forrest
}

Framework Convention Alliance, Geneva, Switzerland

\section{Correspondence to} Dr Sara Rose Taylor, Framework Convention Alliance, 1211 Geneva, Switzerland; rosetaylors@fctc.org

Received 31 May 2021 Accepted 9 November 2021
Check for updates

(C) Author(s) (or their employer(s)) 2022. No commercial re-use. See rights and permissions. Published by BMJ.

To cite: Rose Taylor S, Forrest R. Tob Control 2022:31:335-339.

\section{ABSTRACT}

Since its entry into force in February 2005, the WHO Framework Convention on Tobacco Control (FCTC) has had many significant achievements. It is one of the most widely ratified treaties within the United Nations; its Conference of the Parties has adopted many highquality implementation guidelines, and implementation of the policy guidance in the treaty and its guidelines have decreased tobacco consumption and prevalence. Despite the effectiveness of these measures, however, FCTC implementation has been highly uneven across countries. A medium-term strategic plan was launched to clearly articulate a small number of priority areas for action in order to accelerate the pace of progress - the Global Strategy to Accelerate Tobacco Control (20192025)_but several barriers block its success, including the chronic lack of sustainable, long-term funding. Governments need adequate funds in order to implement FCTC policies and interventions, but many do not have the necessary resources. The global funding gap for tobacco control has been estimated at US\$427.4 billion, with no signs of shrinking in the face of the ongoing pandemic. This paper is concerned with the analysis of solutions to the funding gap problem, assessing possibilities according to feasibility, opportunities, and past or potential effectiveness. Existing solutions include Official Development Assistance, FCTC extrabudgetarily funded projects like the FCTC 2030 project and domestic resource mobilisation via tobacco taxation. The paper will also consider new options including pooled funding mechanisms. Ultimately, a combination of solutions must be pursued in order to ensure Parties' national tobacco control budgets are funded in line with FCTC and Global Strategy priorities.

The WHO Framework Convention on Tobacco Control (FCTC) is one of the most widely ratified treaties in the history of the United Nations (UN). Its Conference of the Parties (COP) has developed and adopted detailed, evidence-based guidelines, and implementation of the treaty provisions and the guidelines have decreased tobacco consumption and prevalence. ${ }^{12}$ Despite the effectiveness of these measures, FCTC implementation has been slow and highly uneven across countries. ${ }^{3}$

Drastic accelerated action will be required to meet global targets to reduce tobacco use prevalence by $30 \%$ by $2025,{ }^{4}$ as well as commitments in the Sustainable Development Goals. At its eighth session in 2018, the COP adopted a strategic plan-the Global Strategy to Accelerate Tobacco Control-to clearly articulate targeted priorities in order to do this. ${ }^{5}$ Several barriers stand in the way of its success, however, including a chronic lack of sustainable resources for FCTC implementation in low/middle-income countries (LMICs) which often have large funding gaps, low average tax rates, and/ or are further from reaching full implementation than high-income countries (HICs).

The imperative to provide LMICs with technical and financial assistance to fulfil their FCTC obligations has been acknowledged from the earliest days of treaty negotiations. ${ }^{6}$ However, the level of international investment in tobacco control has remained extremely low in both absolute terms and relative to other global health issues. Tobacco control expenditure in LMICs in 2017 was estimated at US\$0.0048 per capita, ${ }^{7}$ well below the required US $\$ 0.11$ to implement the four best-buy tobacco control measures. ${ }^{8}$ Further, in 2019, development assistance for tobacco control programmes amounted to US\$66 million, or $0.16 \%$ of all development assistance provided for health-related causes, with the majority provided by philanthropies. ${ }^{9}$ Crude estimates suggest a gap of US $\$ 27$ billion between existing domestic and international resources and those required to achieve a global scale-up of the treaty's demand-reduction measures. ${ }^{10}$

Achieving further progress on treaty implementation and the Global Strategy will require a concerted effort to mobilise substantial additional resources for tobacco control to close the resource gap. Several options exist for doing so (table 1), varying in their feasibility, sustainability and effectiveness. This paper outlines and analyses a targeted selection of these potential solutions, both those that have been employed (but underused) to date and potential new solutions. In so doing, the paper revisits a critical issue that receives inadequate attention many years after FCTC negotiation. Tobacco control funding in the context of the pandemic and COVID-19 recovery efforts is also considered.

\section{ONGOING SOLUTIONS TO TOBACCO CONTROL'S FUNDING GAP PROBLEM}

Various sources of funds have been used over the years to generate resources required for global and national-level tobacco control programmes and initiatives. These include, but are not limited to, domestic resource mobilisation (DRM), official development assistance (ODA), support provided through the FCTC Secretariat, and charges and levies applied to tobacco companies. These approaches, outlined below, represent options for addressing the funding gap on multiple fronts, but only if applied more strongly and for longer time horizons to adequately fund tobacco control to FCTC-compliant levels. ${ }^{11} 12$ Many other options also exist, including philanthropic assistance and sector budget support; although these options have 
Table 1 Possible revenue sources for tobacco control

\begin{tabular}{|c|c|}
\hline Options and key ideas & Summary \\
\hline Domestic resource mobilisation & $\begin{array}{l}\text { A process of collecting and spending funds } \\
\text { to provide for the people of a given country. } \\
\text { Tobacco taxation is a key example. }\end{array}$ \\
\hline Official development assistance (ODA) & $\begin{array}{l}\text { Bilateral, concessional aid provided by } \\
\text { governments with the main objective } \\
\text { of promoting economic development } \\
\text { and welfare. Given that tobacco control } \\
\text { contributes to economic development and } \\
\text { welfare, it is a suitable target issue area for } \\
\text { ODA. }\end{array}$ \\
\hline Polluter pays principle & $\begin{array}{l}\text { A commonly accepted practice in } \\
\text { environmental law where the polluter should } \\
\text { pay for the costs of measures to reduce } \\
\text { pollution. In the case of tobacco control, it } \\
\text { would mean that tobacco companies should } \\
\text { bear the costs of measures to reduce the } \\
\text { harms caused by tobacco. }\end{array}$ \\
\hline Regulatory fees & $\begin{array}{l}\text { Payments charged to businesses by } \\
\text { governments in order to support the } \\
\text { regulation of a profession or business. This } \\
\text { includes licences and cost recovery fees. }\end{array}$ \\
\hline Tax on Repatriated Tobacco Profits & $\begin{array}{l}\text { A transaction tax on the tobacco-related } \\
\text { profits that flow from countries where } \\
\text { cigarettes are sold to countries where profits } \\
\text { are distributed. }\end{array}$ \\
\hline Support provided via the FCTC Secretariat & $\begin{array}{l}\text { Extrabudgetary funding that Parties to the } \\
\text { FCTC can voluntarily provide to fund the } \\
\text { budget and workplan, often earmarked for } \\
\text { specific projects or activities. }\end{array}$ \\
\hline
\end{tabular}

FCTC, Framework Convention on Tobacco Control.

provided required funds thus far, they may not be sustainable in the long-term due to their unpredictability, potentially limited alignment with government priorities and other concerns (see also ${ }^{12}$ ). The options highlighted in this paper represent those that may be best harnessed moving forward.

DRM is a process of collecting and spending funds to provide for national budgets. Once in place, it can provide the sustainable long-term funding that tobacco control programmes require. One important type of DRM is tobacco tax revenue, which can provide significant financial and health opportunities for a country including increasing government revenue, decreasing the health and economic costs of tobacco use, increasing health outcomes, and meeting international commitments in the FCTC and the Addis Ababa Action Agenda. ${ }^{13}$ One key example is the 2012 Philippines 'sin tax reform', which increased year-overyear excise tax revenue from tobacco by $85.6 \%$. The majority of this funding provided healthcare subsidies for the poorest in the country. ${ }^{14}$ Other countries with earmarked tobacco tax revenue for tobacco control or other health spending include Botswana, Egypt, Iceland, Panama and Vietnam. ${ }^{15}$ Increasing tobacco taxes represents a significant opportunity for LMICs because, for most of these countries, tobacco tax revenue is less than $1 \%$ of Gross Domestic Product (GDP), so there is untapped, sustainable revenue potential. ${ }^{16}$ In addition, most countries fall below the WHO's recommended excise tax level of $70 \%{ }^{17}$ of the retail price of cigarettes. ${ }^{18}$ Better use of this funding option would require strengthening tobacco taxation systems, and in many cases taxation systems more generally, with improved coordination between Ministries of Finance and Health and the Treasury to align taxation and budgeting for tobacco control, in order to ensure this option is sustainable in the long run. ${ }^{12}$

A second ongoing approach is bilateral ODA to LMICs. We refer here to ODA as concessional aid provided by governments with the main objective of promoting economic development and welfare. ${ }^{19}$ ODA can provide financial resources for tobacco control activities at no cost (grants) or at discounted costs (loans) for countries where, for example, DRM is not yet a viable option for financing tobacco control. One of the benefits of ODA is that it often brings technical assistance and policy dialogue, and as such is well suited to building tobacco control capacity ${ }^{20}$; this was the case in the New Zealand Agency for International Development-funded six-country, 5-year, comprehensive tobacco control project in the Pacific Islands between 2003 and $2007 . .^{21}$ At the same time, however, aid conditionalities and the practice of 'tying' aid to using specific processes or supply chains can contribute to decreased effectiveness, and bilateral aid can contribute to overall aid fragmentation ${ }^{22}$ which can impact its options as a sustainable funding source for tobacco control. This could be tempered by channelling aid through multilateral options (including through the FCTC Secretariat; see below).

In general, bilateral aid has been underused as a means of financing tobacco control. A report for COP4 in 2010 found that financial and technical support provided to LMIC Parties had been underimplemented ${ }^{22} 23$ and it appears that has not changed; data from the Organisation for Economic Co-operation and Development's Development Assistance Committee (OECD DAC) indicate that in 2019, disbursements of bilateral ODA for tobacco control amounted to US\$1.48 million. ${ }^{24}$ This may be due, in part, to low awareness among donor agencies of the development dimensions of tobacco use and control as well as a lack of prioritisation of tobacco control within national development planning documents and frameworks. ${ }^{25}$ However, the FCTC's inclusion in the Sustainable Development Goals under Target 3.a, in combination with FCTC Articles on providing financial assistance, sets a foundation on which stakeholders can build arguments for better harnessing this funding avenue as a sustainable source of income over a longer time horizon. Much will also depend on the COVID-19 pandemic's impact on ODA (see next section).

A third ongoing solution is the support available to Parties under the FCTC COP and its Secretariat. FCTC Article 5.6 calls on Parties to "cooperate to raise financial resources for effective implementation of the Convention through bilateral and multilateral funding mechanisms'. Articles 20.5, 23.5 and 26 outline further obligations of Parties with respect to providing financial resources, including to support developing country Parties and Parties with economies in transition. In recent years, a number of HICs have provided funding to support FCTC implementation in LMICs via the Convention Secretariat, perhaps the most notable example being the FCTC2030 programme, established with an initial $£ 15$ million grant from the UK in 2016 and supplemented thereafter by funds from Australia and Norway. ${ }^{26}$ The programme provides funding to Parties eligible for ODA to achieve general obligations and time-bound measures of the treaty, in line with the Global Strategy.

Despite these recent developments, financial assistance provided by Parties under the FCTC is still low relative to need. The total 2020-2021 budget for technical assistance to facilitate implementation, including but not limited to FCTC2030, is US\$5.5 million ${ }^{27}$; a small share of what is needed to address the estimated US\$27 billion global funding gap to scale up the treaty's demand-reduction measures. Implementation support has been funded through extrabudgetary contributions (EBFs): funding provided voluntarily by Parties, outside the Convention's core budget and often earmarked for specific purposes. EBFs are less stable and predictable than funding provided through the core FCTC budget, and the accepted practice of earmarking allows donor countries to influence priorities, 
potentially undermining the efficacy of frameworks like the Global Strategy. To fund accelerated progress on FCTC implementation and better harness this solution, there are two recommended options which should both be pursued. First, the COP should explore increasing assessed contributions, as the current budget they provide limits the scope of core activities. ${ }^{28}$ The total amount of assessed contributions has remained stagnant despite an increase in budget and in the number of Parties over the years; increasing stable assessed contributions is more sustainable in the long run. Second, Parties should commit to increasing EBFs either as flexible contributions or, if earmarked, as contributions that clearly are aligned with COP priorities including but not limited to those outlined in the Global Strategy.

A fourth category of ongoing solution is to extract financial resources from the tobacco industry in the form of regulatory charges and/or applying levies on tobacco companies. These solutions would hold the tobacco industry financially accountable for their costs to governments and societies; a notable difference from tobacco taxes, where consumers bear a financial cost as opposed to producers/suppliers.

Regulatory charges, which are payments required by governments to support the regulation of a profession or business, would include licences and cost recovery fees. They are charged by a government to cover costs of their tobacco control strategies and programmes designed to regulate the tobacco industry nationally. France and Vietnam both extract contributions to tobacco control funds from the tobacco industry; France charges based on wholesale revenue while Vietnam charges based on sales revenue. ${ }^{29}$

Additionally, levies on tobacco companies can be applied according to the polluter pays principle: a 'polluter should bear the cost of measures to reduce pollution according to the extent of either damage done to society or the exceeding of an acceptable level (standard) of pollution, ${ }^{30}$ It is a commonly accepted practice in environmental law and could logically be extended to tobacco control, where tobacco companies should bear the cost of measures to reduce the harms caused by tobacco consumption and production. Under this approach, a levy on tobacco companies could be used to fund FCTC implementation. $^{28} 3132$ This could be in the form of a Tax on Repatriated Tobacco Profits, a transaction tax on the profits that flow from countries where cigarettes are sold to countries where profits are distributed-which in many cases would address the imbalance between profits earned in LMICs that are sent to HICs. ${ }^{31}$ Based on Callard's ${ }^{31}$ estimates of transnational tobacco companies' profits, a $1 \%$ tax on repatriated profits could yield $\$ 200$ million per year towards FCTC implementation. ${ }^{28}$

\section{POSSIBLE NEW SOLUTIONS}

Looking forward, the tobacco control community should not only work to improve the resource-creation possibilities of existing solutions outlined above, but also explore new funding gap solutions. Two such solutions stand out at this time: in-country budget advocacy to increase national tobacco control spending, and a global-level pooled funding mechanism. Applying all of these solutions, both ongoing and new, must take into account how they may fit into post-pandemic recovery.

One novel solution involves building the skills and capacity of civil society for budget advocacy: a strategic approach to analysing and influencing government budgets, aimed at increasing allocations for an entire sector or specific programme area. ${ }^{33}$ In the case of tobacco control, its goal might be to increase allocations for tobacco control programmes commensurate with need.
Achieving stable, long-term allocations from domestic budgets is the most sustainable option for financing tobacco control, which requires continuous action over many years to achieve progress. Relying too much on external finance can leave tobacco control programmes vulnerable if it is withdrawn suddenly or unexpectedly.

Budget advocacy seeks to ensure that public resource allocation decisions reflect the health and economic burden of tobacco use in a given country, as well as the return on investment that FCTC implementation can deliver. Difficulties accessing and communicating this kind of information to those working in sectors beyond health have been identified as a major obstacle to domestic resource mobilisation for tobacco control. ${ }^{34}$ While work is underway as part of the FCTC2030 project to support governments' access to and use of the information and tools that may support their efforts to make the case for domestic investment in tobacco control, such as through the development of costed national tobacco control strategies, ${ }^{35}$ the role of civil society in supporting this kind of work has been underexplored. The potential for civil society to successfully hold governments to account and increase resourcing for various health-related causes through budget advocacy has been well documented (for example, by the International Budget Partnership). However, the authors are aware of very few efforts to support civil society to undertake this kind of work in tobacco control. Necessary support might include training on national budget processes and funding to conduct advocacy and public awareness-raising campaigns.

Another possible solution is a pooled funding mechanism. Pooled funds include multidonor trust funds (MDTFs) and vertical funds; the former is a multiagency funding mechanism held in trust by an administrative agent ${ }^{36}$ and the latter is a fund governed by an independent board and confined to a particular thematic issue. ${ }^{37}$ Both types of funds can be found under various other conventions and international treaties, including smaller MDTFs like under the World Heritage Convention or massive vertical funds such as the Green Climate Fund under the UN Framework Convention on Climate Change. Funding for these mechanisms can come from a variety of sources, depending on fund design, including from national governments (including health departments and development agencies), philanthropic organisations and international organisations. Funding sources could also include other innovative financing mechanisms, including a Solidarity Tax Levy on tobacco products ${ }^{28}$ or a Tax on Repatriated Tobacco Profits to add a levy on tobacco-related profits. ${ }^{28} 31$ A wide range of sources of capital increases its viability and sustainability.

Currently, the FCTC does not have a pooled funding mechanism, although an investment fund was proposed at COP8 and is up for potential adoption at COP9. During treaty negotiations and COP1, developing countries repeatedly called for the creation of a global fund (for details, see INB summary $\left.\operatorname{records}^{38-43}\right)$, though it was ultimately decided by COP1 and COP2 that existing resources should first be assessed and tapped and a global fund was not established. ${ }^{28}{ }^{44}$ Since then, there has been no further discussion at the FCTC COP about such a fund, but it could benefit from the flexibility and predictability that such a solution would provide. The mechanism could be used to fund FCTC implementation in LMICs that require financial support given their tobacco control funding gaps, ${ }^{10}$ as recognised in the Global Strategy, ${ }^{5}$ offering a clear pitch to donors and a centralised body to coordinate funding efforts. Allowing for a range of voluntary contributions, including from non-country donors in line with FCTC Article 5.3 on the protection of public 
health policies with respect to tobacco control from commercial and other vested interests of the tobacco industry, can help ensure a sizeable mechanism with the funds required to support many projects. It would be valuable for funding recipients if earmarking of funds was limited, given the inflexibility of conditions which may not be responsive to recipient needs. Given that various other blueprints exist under other conventions and treaties, and the increasing popularity of such funds, ${ }^{45}{ }^{46}$ a pooled funding mechanism for FCTC implementation represents a realistic and sustainable option to pursue in addressing the global funding gap. ${ }^{12}$

Finally, any discussion of funding for tobacco control must take into consideration the unique economic and political context of the COVID-19 pandemic, which poses both challenges and opportunities. Finding the resources for tobacco control programmes from both international and domestic sources may prove more challenging in the face of the massive deficits governments around the world currently face. ${ }^{478}$ At the same time, however, the pandemic creates new urgency. With health systems in disarray the world over, ${ }^{49} 50$ there is an increasingly strong case for investing in population-level preventive measures to reduce future healthcare expenditure and foster health system resiliency. Likewise, the pandemic creates opportunities to highlight the particular role that tobacco taxes can play in generating revenue at a time when it is sorely needed. Estimates suggest that a tobacco tax increase that raises the price of tobacco by $20 \%$ would lead to a US $\$ 27$ billion increase in tax revenue over 50 years. ${ }^{51}$ As such, it will be critical for the tobacco control community to ensure that tobacco control is included as part of discussions on 'building back better'.

\section{CONCLUSIONS}

Ultimately, a combination of solutions must be pursued to ensure Parties' tobacco control budgets are funded in line with FCTC and Global Strategy priorities. Initially, this means making better use of current solutions. To effectively and sustainably fund FCTC progress, these existing approaches must be applied more strongly by more partners and with longer time horizons. It would also be valuable for the tobacco control community to explore and pursue new solutions including budget advocacy to improve national-level public resource allocation as well as a pooled funding mechanism to fund implementation in LMIC Parties lacking necessary resources. Without stronger action to sustainably address the global funding gap, LMICs face the risk of falling even further behind in implementing proven FCTC measures. Collective action is urgently needed to address the critical threat that the global funding gap poses to health and development.

\section{What this paper adds}

- Ongoing solutions to fund global tobacco control include domestic resource mobilisation, official development assistance, and support provided through the Framework Convention on Tobacco Control (FCTC) and its Secretariat. These options must be applied even more strongly and for longer time horizons in order to adequately fund tobacco control to FCTC-compliant levels.

- The tobacco control community should not only work to improve the resource-creation possibilities of the ongoing solutions, but also explore new solutions to the global funding gap problem such as in-country budget advocacy to increase national spending on tobacco control and a globallevel pooled funding mechanism.
Contributors Both authors contributed equally to the research, writing, editing and revisions of this document.

Funding The authors have not declared a specific grant for this research from any funding agency in the public, commercial or not-for-profit sectors.

Competing interests None declared.

Patient consent for publication Not required.

Ethics approval This study does not involve human participants.

Provenance and peer review Commissioned; externally peer reviewed.

ORCID iD

Sara Rose Taylor http://orcid.org/0000-0002-9466-6166

\section{REFERENCES}

1 Hoffman SJ, Tan C. Overview of systematic reviews on the health-related effects of government tobacco control policies. BMC Public Health 2015;15:744.

2 Chung-Hall J, Craig L, Gravely S, et al. Impact of the who FCTC over the first decade: a global evidence review prepared for the impact assessment expert group. Tob Control 2019:28:s119-28.

3 World Health Organization. Who report on the global tobacco epidemic 2019: offer help to quit tobacco use. Geneva, 2019. Available: https://www.who.int/publications/ i/item/9789241516204

4 World Health Organization. Who global report on trends in prevalence of tobacco use 2000-2025, third edition. Geneva, 2019. Available: https://www.who.int/publications/ i/item/who-global-report-on-trends-in-prevalence-of-tobacco-use-2000-2025-thirdedition

5 WHO FCTC Conference of the Parties. Measures to strengthen implementation of the Convention through coordination and cooperation (Decision FCTC/COP8(16)) Geneva, 2018. Available: https://www.who.int/fctc/cop/sessions/cop8/FCTC__COP8( 16).pdf

6 WHO FCTC Conference of the Parties. Financial resources and mechanisms of assistance (Decision FCTC/COP1(13)). Geneva, 2006. Available: https://apps.who.int/ iris/handle/10665/75583

7 World Health Organization. WHO report on the global tobacco epidemic 2017: monitoring tobacco use and prevention policies. Geneva, 2017. Available: https:// apps.who.int/iris/handle/10665/255874

8 World Health Organization. Scaling up action against NCDS: how much will it cost? Geneva, 2011. Available: http://whqlibdoc.who.int/publications/2011/ 9789241502313 eng.pdf

9 Institute for Health Metrics and Evaluation. Financing global health 2019: tracking health spending in a time of crisis, 2020. Available: http://www.healthdata.org/policyreport/financing-global-health-2019-tracking-health-spending-time-crisis

10 Research Triangle Institute. International financing gap to implement demand reducing tobacco control strategies in who FCTC countries, 2018. Available: https:// www.fctc.org/wp-content/uploads/2019/02/FCTC-Funding-Gap-Report_9_18.pdf

11 Forrest R, Taylor SR, Rose Taylor $\mathrm{S}$. It is time to become serious about closing the global resource gap for FCTC implementation. Tob Induc Dis 2020;18:1-2.

12 Framework Convention Alliance. Options for sustainable funding mechanisms for FCTC implementation, 2022.

13 United Nations General Assembly. Addis Ababa action agenda of the third International Conference on financing for development (Addis Ababa action agenda). A/RES/69/313, 2015.

14 Booth D. Aiding institutional reform in developing countries. San Francisco, us: the Asia Foundation, and; London, UK: overseas development Institute, 2014. Available: https://odi.org/en/publications/aiding-institutional-reform-in-developing-countrieslessons-from-the-philippines-on-what-works-what-doesnt-and-why/

15 World Health Organization. Earmarked tobacco taxes: lessons learnt from nine countries. Geneva, 2016. Available: https://www.who.int/publications/i/item/ 9789241515825

16 Vulovic V. Economic costs of tobacco use. Chicago, US: Tobacconomics, 2019: 1-7. https://tobacconomics.org/files/research/523/UIC_Economic-Costs-of-Tobacco-UsePolicy-Brief_v1.3.pdf

17 World Health Organization. Guidelines for implementation of the who FCTC. Geneva, 2013. Available: https://www.who.int/fctc/treaty_instruments/adopted/guidel_2011/ en/

18 Inter-agency Task Force on Financing for Development. Financing for development: progress and prospects 2018. New York, 2018. Available: https://www.un.org/ development/desa/publications/financing-for-development-progress-and-prospects2018.html

19 Organization for economic cooperation and development definition of official development assistance. Available: https://www.oecd.org/dac/financing-sustainabledevelopment/development-finance-standards/official-development-assistance.htm\#: : text=0fficial\%20development $\% 20$ assistance $\% 20($ ODA)\%20is, and\%20welfare\% 20of\%20developing\%20countries [Accessed May 2021].

20 Organization for Economic Cooperation and Development. The DAC guidelines: poverty reduction, 2001 
21 Allen M. Overseas development assistance programmes for tobacco control: a framework for effective action. Wellington, 2012. Available: https://www. allenandclarke.co.nz/wp-content/uploads/2016/03/ODA-Tobacco-Document.pdf

22 Biscaye PE, Reynolds TW, Anderson CL. Relative effectiveness of bilateral and multilateral aid on development outcomes. Rev Dev Econ 2017;21:1425-47.

23 WHO FCTC Conference of the Parties. Financial resources and mechanisms of assistance (document A/FCTC/COP/4/16). Geneva, 2010. Available: https://apps.who. int/gb/fctc/PDF/cop4/FCTC_COP4_16-en.pdf

24 Data from OECD statistics Creditor reporting system 2021.

25 United Nations Development Programme. Development planning and tobacco control. New York, 2014. Available: https://www.undp.org/publications/ development-planning-and-tobacco-control-integrating-who-frameworkconvention-tobacco

26 Who framework convention alliance. FCTC 2030. Available: https://www.who.int/fctc implementation/fctc2030/en/\#: :text=a)\%20on\%20the\%20implementation\%20of, April\%202017\%20to\%20March\%202021 [Accessed May 2021].

27 WHO FCTC Conference of the Parties. Worldplan and budget for the financial period 2020-2021 (Decision FCTC/COP8(10)), 2018. Available: https://www.who.int/fctc/ cop/sessions/cop8/FCTC_COP8(10).pdf?ua=1

28 Munoz V, DK S, Syan N. Financial resources for implementation of tobacco control measures: potential of innovative financing. Geneva, 2013. Available: https://idl-bncidrc.dspacedirect.org/bitstream/handle/10625/52431/IDL-52431.pdf

29 Physicians for a smoke-free Canada. regulatory charges on tobacco suppliers, 2021. Available: http://www.smoke-free.ca/SUAP/2021/regulatory\%20fees.pdf

30 United Nations Statistics Division. Glossary of environment statistics, studies in methods, series F, no. 67. New York, 1997. Available: https://unstats.un.org/unsd/ publication/seriesf/seriesf_67e.pdf

31 Callard C. Follow the money: how the billions of dollars that flow from smokers in poor nations to companies in rich nations greatly exceed funding for global tobacco control and what might be done about it. Tob Control 2010;19:285-90.

32 DK S, Syam N, Velásquez G. Innovative financing mechanisms: potential sources of financing the who tobacco convention. Geneva, 2014. Available: https:// www.southcentre.int/wp-content/uploads/2014/09/RP54_Innovative-FinancingMechanisms-rev_EN.pdf

33 Save the Children. Health sector budget advocacy: a guide for civil society organisations. London, 2012. Available: https://www.who.int/pmnch/media/news/ 2012/201205_health_sector_budget_advocacy.pdf?ua=1

34 WHO FCTC Conference of the Parties. Sustainable measures to strengthen implementation of the who FCTC (document FCTC/COP/6/19), 2014. Available: https://apps.who.int/gb/fctc/PDF/cop6/FCTC_COP6_19-en.pdf

35 Governance and Social Development Resource Centre. Helpdesk research report: trus funds in fragile and low capacity states, 2011. Available: http://www.gsdrc.org/docs/ open/hd740.pdf

36 Independent Evaluation Group. Trust fund support for development: An evaluation of the World Bank's trust fund portfolio. Washington, 2011. Available: http://hdl.handle. net/10986/21345
37 Browne S, Cordon R. Vertical funds: lessons for multilateralism and the un, 2015. Available: https://www.futureun.org/media/archive1/briefings/FUNDS_Brief25_ Jan2015_WHO_GAVI_GF.pdf

38 Intergovernmental negotiating body on the who framework convention on tobacco control, first session. summary records (document A/FCTC/INB1/SR), 2000. Available: https://apps.who.int/gb/fctc/PDF/inb1/FINAL_FCTC_INB1_SR_COMPILATION.pdf

39 Intergovernmental negotiating body on the who framework convention on tobacco control, second session. summary records (document A/FCTC/INB2/SR), 2001. Available: https://apps.who.int/gb/fctc/PDF/inb2/FINAL_FCTC_INB2_SR_ COMPILATION.pdf

40 Intergovernmental negotiating body on the who framework convention on tobacco control, third session. summary records (document A/FCTC/INB3/SR), 2001. Available: https://apps.who.int/gb/fctc/PDF/inb3/FINAL_FCTC INB3 SR COMPILATION.pdf

41 Intergovernmental negotiating body on the who framework convention on tobacco control, fourth session. summary records (document A/FCTC/INB4/SR), 2002. Available: https://apps.who.int/gb/fctc/PDF/inb4/FINAL_FCTC_INB4_SR_ COMPILATION.pdf

42 Intergovernmental negotiating body on the who framework convention on tobacco control, fifth session. summary records (document A/FCTC/INB5/SR), 2002. Available: https://apps.who.int/gb/fctc/PDF/inb5/FINAL_FCTC_INB5_SR_COMPILATION.pdf

43 Intergovernmental negotiating body on the who framework convention on tobacco control, sixth session. summary records (document A/FCTC/INB6/SR), 2003. Available: https://apps.who.int/gb/fctc/PDF/inb6/FINAL_FCTC_INB6_SR_COMPILATION.pdf

44 WHO FCTC Conference of the Parties. Summary records of committees. reports of committees. Geneva, 2006. Available: https://apps.who.int/iris/handle/10665/75576

45 Manuel M, Manuel C. Achieving equal access to justice for all by 2030: lessons from global funds. London, 2018. Available: https://odi.org/en/publications/achievingequal-access-to-justice-for-all-by-2030-lessons-from-global-funds/

46 Reinsberg B, Michaelowa K, Eichenauer V. The rise of multi-bi aid and the proliferation of trust funds. In: Arvin BM, Law B, eds. Handbook on the economics of foreign aid. Cheltenham, UK: Elgar, 2015: 527-54

47 International Monetary Fund. World economic outlook: managing divergent recoveries, April 2021. Washington, DC, 2021. Available: https://www.imf.org/en/ Publications/WEO/Issues/2021/03/23/world-economic-outlook-april-2021

48 Organization for Economic Cooperation and Development. Six decades of ODA: insights and outlook in the COVID-19 crisis. Paris, 2020. Available: https://www.oecdilibrary.org/development/development-co-operation-profiles_5e331623-en

49 World Health Organization. Pulse survey on continuity of essential health services during the COVID-19 pandemic: interim report, 2020. Available: https://apps.who.int/ iris/handle/10665/334048

50 World Health Organization. Rapid assessment of service delivery for NCDS during the COVID-19 pandemic. Geneva, 2020. Available: https://www.who.int/publications/m/ item/rapid-assessment-of-service-delivery-for-ncds-during-the-covid-19-pandemic

51 Summan A, Stacey N, Birckmayer J, et al. The potential global gains in health and revenue from increased taxation of tobacco, alcohol and sugar-sweetened beverages: a modelling analysis. BMJ Glob Health 2020;5:e002143. 